\title{
The Influence of Financial Knowledge, Financial Attitude, and Personality on Financial Management Behavior on XYZ Islamic Boarding School Ponorogo
}

\author{
Defri Ramadan Wardiansyah ${ }^{1}$, Nur Khusniyah Indrawati ${ }^{2}$ \\ Faculty of Economics and Business \\ Brawijaya University \\ Defriramadanwardiansyah@outlook.com
}

\begin{abstract}
The presence of financial technology that often offers and discounts impacting on individual consumptive attitudes, which often makes individuals experience a condition of a financial deficit. This study aims to analyze the effect of financial knowledge, financial attitudes, and personality traits on personal financial management behavior. The population of this research is the teaching staff at one of the Islamic boarding schools in Ponorogo City. The sampling technique used in this study is the saturated sampling technique with a sample size of 31 respondents. The data analysis technique in this study used the PLS structural equation model with the help of the SmartPLS 3.0 program. There is a significant positive effect between financial attitudes and personal financial management behavior.

Keywords: Financial Knowledge, Financial, Attitude, Personality Traits, Personal Financial Management Behavior.
\end{abstract}

$\begin{array}{ll}\text { JEL } & : \text { G40 } \\ \text { DOI } & : 10.24002 / \text { kinerja.v25i2.4772 }\end{array}$

Received : 08/03/2021 Reviewed: 08/04/2021 Final Version: 08/12/2021

\section{INTRODUCTION}

The rapid development of technology in recent years has had a huge impact on the behavior of the Indonesian people. The presence of advertisements that utilize technological sophistication so that they are able to easily attract people to buy the products offered leads to consumptive financial behavior. Based on data from the Indonesian Internet Service Providers Association (APJII), the number of 
internet users this year will grow to $60 \%$ of the total number of users in 2018 , which was 143.26 million users.

The development of financial technology also has a big contribution to consumptive behavior in society. Ease of carrying out various financial transactions and the presence of discount and cashback programs that can easily trap people to spend their financial resources by increasing the sources of people's consumptive behavior. Schueffel (2016) states that financial technology is a new industry that is developing in the financial world that applies information technology with the aim of increasing the efficiency of financial activities.

Consumptive behavior arises as a result of the desire to have objects that are considered to be able to bring satisfaction to someone when they are able to have these objects. A person who has consumptive behavior tends to be difficult to distinguish between the object of desire or the object of need. (Kapoor et al., 2007) states that a need is something that an individual must have to survive, while a desire is something that an individual wants to have or do.

Achieving financial health requires a strong commitment to distinguish between wants and needs, thereby reducing the chances of an individual falling into a financial deficit condition. A financial deficit condition is a condition in which a person has an expenditure that is greater than the amount of income received (Kapoor et al., 2007), so that to avoid a financial deficit, good financial management behavior is needed. According to Kholilah and Iramani (2013) the ability of an individual to manage daily financial resources to meet the needs of an individual life is a financial management behavior.

Several factors influence personal financial management behavior, the first factor is financial knowledge (Ahillah, 2019), where the statement is supported by the theory of planned behavior which acts as the basis for the statement.

The theory of planned behavior is a theory that has the assumption that intentions or goals are the basis of an individual in carrying out a certain behavior or action and is motivated by several factors such as personal factors, social factors, and information factors (Ajzen, 2005). Information can be interpreted as knowledge which is very crucial in the decision-making process. The financial knowledge variable is used in this study to prove whether the financial knowledge possessed by individual influences the individual's financial management behavior.

The second factor is the financial attitude of an individual. Pradiningtyas and Lukiastuti (2019) state that how an individual determines the actions to be taken in the future, especially in the financial sector by paying attention to the individual's psychological factors such as the individual's state, thoughts, opinions, and assessments of the financial condition he currently has is referred to as financial attitude (hereinafter in this study will be referred to as financial attitude). 
Many individuals of productive age have a bad attitude in assessing their finances, where most individuals feel that the condition of their personal finances will always be fine even though the individual takes actions that tend to be consumptive and ultimately end up regretting not having enough financial resources when an emergency condition occurs. A good financial attitude in an individual indicates that the individual has a good mindset and view of finance so that the individual will always try to control himself and not follow his desires so that he has good financial management (Asaff et al, 2019). The financial attitude variable is used in this study to prove whether the financial attitude possessed by individual influences the individual's financial management behavior.

The third factor is personality (personality traits). Sina (2014) states that understanding the personality of each individual is needed to achieve financial security and freedom because each individual has a different personality type and will do different financial planning. Based on the theory of big-five personality traits, personality is the way in which an individual reacts and interacts with the environment or with other individuals. The personality variable is used in this study to prove whether the individual personality influences the individual's financial management behavior.

The object of this research is educators at one of the Islamic boarding schools in Ponorogo City. The object of this research was chosen because there are still not many studies that take the object of Islamic boarding schools so that it is hoped that this research can be the beginning of research on financial knowledge, financial attitudes, personality traits, and personal financial management behavior.

Based on the introduction that has been described, this study aims to determine and analyze the significant influence of financial knowledge, financial attitude, and personality on personal financial management behavior.

\section{LITERATURE REVIEW}

\subsection{Theory of Planned Behavior}

The theory of planned behavior is a theory by Icek Ajzen which is the result of the development of the theory of reasoned action which was developed in 1988. The theory of planned behavior has the basis that the belief of an individual is able to influence the individual to carry out certain behaviors. The theory of planned behavior assumes that an individual's behavior depends on factors such as attitude, subjective norm, and perceived behavioral control owned by the individual, where these three factors are often referred to as behavioral intentions (Ajzen, 1991).

The attitude component that is part of behavioral intention has a scope of beliefs that are believed by an individual about how the individual assesses the objects being faced. The subjective norm component includes the various ways used by individuals to place their perspective on the expectations of the 
environment around them and whether the individual will act under the expectations of the environment or not. The last component of behavioral intention is perceived behavior control which includes how an individual sees a certain opportunity to perform a behavior through various considerations such as the possibility of obstacles or ease and difficulty in carrying out a certain behavior. The following is a theoretical model of the theory of planned behavior which consists of several variables:

\section{Background factor}

According to Ajzen (1991), the background of the behavior taken by an individual is influenced by 3 factors. The first is the personal factor which is the general attitude that the individual has towards a thing or object in the form of personal personality traits, the values of life that are believed to be, and the cognitive intelligence of the individual. The second is the social factors of an individual such as the level of age, gender, ethnicity or race, education level, amount of income owned, and the religion adhered to by the individual. The third is information factors such as experiences that have been experienced, the knowledge that has been learned, and exposure to the media.

\section{Behavioral beliefs}

Various things that are believed by individuals about the positive or negative assessment of behavior that has an impact on how the individual's affective reaction to assessing a certain behavior is expressed by an individual in the form of feelings of liking or disliking.

3. Normative belief

A condition of the environment in which individuals interact with other individuals. Decisions taken by individuals can be influenced by other individuals who have a certain influence (significant others) on the individual.

4. Subjective norm

How an individual acts in response to the other individual behaviors, whether he will be motivated to act or not if other individuals provide an external view of the attitude to be taken.

\section{Control belief}

Various things that control the attitude or action of an individual obtained from knowledge, skills, experience, availability of time and facilities to carry out an action or behavior, as well as the ability of the individual to overcome difficulties that hinder the process of behaving. 


\section{Perceived behavioral control}

A belief about certain behaviors that have been carried out or have not been carried out which are believed by an individual.

\subsection{Financial Knowledge}

Gardner (in Maghfirah, 2019) states that the process of using the five senses possessed by an individual to produce knowledge or skills on a particular object is referred to as knowledge. The knowledge possessed by individuals can be divided into several levels. According to Notoatmodjo (2005), there are 6 levels of knowledge including:

1. Know

The first level of knowledge and is the lowest level, where an individual is only able to know and recall what is being learned such as mentioning, describing, giving definitions, and giving statements.

\section{Comprehension}

The level of knowledge at which an individual has the capability to understand what is being studied. Understanding here is defined as the individual's ability to re-explain the material that the individual has studied properly and correctly.

\section{Application}

The level of knowledge where an individual has the capability to use previously studied material to be used as a basis for taking action in overcoming a certain situation or condition in real life.

\section{Analysis}

The level of knowledge where an individual has the capability to describe the material or object that has been studied into various smaller components but still in the same structure and has a bond between components with one another.

5. Synthesis

The level of knowledge where an individual is able to put or connect various separate parts into a new, comprehensive form of knowledge.

\section{Evaluation}

The level of knowledge where an individual has the capability to research a particular material or object that has been studied, where the research is 
based on criteria that have been determined independently by the individual or using criteria that have existed in previous studies.

Aprilia (2015) states that the understanding possessed by an individual in mathematical calculations, especially regarding the value of money or interest rates, inflation rates, and various other financial media is the notion of financial knowledge. If an individual has good financial knowledge, it is expected that the individual will be able to form responsible financial decisions. The indicators for measuring financial knowledge according to Marsh (2006) are knowledge of basic financial aspects, knowledge of debt, and knowledge of interest.

\subsection{Financial Attitude}

Ajzen (1991) state that an individual's assessment of either positive or negative on a particular object is the definition of attitude. While the application of attitudes based on the circumstances, thoughts, opinions, and assessments that an individual has regarding finances is the notion of financial attitude (Pankow, 2003).

According to Azwar (2013), the attitude possessed by an individual can be influenced by several factors including the environment, experience, and education. According to Ajzen (1991), there are two classifications in the formation of individual attitudes. The first is behavioral beliefs, which are various beliefs that are believed by an individual towards behavior that encourages the formation of a certain attitude. the second is the Evaluation of behavioral belief which is an individual's assessment of the various beliefs that the individual believes in an attitude seen from the perspective of positive or negative attitude.

The financial behavior of an individual is determined by the financial attitude of the individual (Shih and Ke, 2014). The indicators used to measure financial attitude according to (Marsh, 2006) are orientation to personal finance, debt philosophy, financial security, and assessing personal finances.

\subsection{Personality}

Personality can be interpreted as the characteristics contained in the behavior carried out by an individual. Carl (in Setiawan et al., 2016) states that the thoughts that individuals have, the feelings they feel, and the behaviors that have been carried out in real, both intentional and unintentional, are the meaning of personality.

According to Sjarkawi (in Setiawan et al., 2016), there are two main factors that influence the personality of an individual including internal factors and external factors. Internal factors are factors that come from within an individual which is a genetic factor or carried since the individual was born and is a factor that is directly influenced by the personality or nature of the parents of the individual. While external factors are factors that come from outside of an individual. External factors 
here are in the form of the environment where the individual is located, both in the form of a small environment such as a family to a macro-environment such as the community environment.

Personality theory that reveals and reviews the relationship between cognitive, affective, and psychomotor to the behavior taken by an individual is an understanding of the Big five personality traits (Caprara and Cervone, 2000). So that it can be interpreted that the big five personality traits are a theoretical model capable of explaining the relationship between personality and behavior carried out by an individual. According to Subiaktono (2013), the dimensions that can be used to measure personality based on the Mowen 3M Hierarchical Model are agreeableness, conscientiousness, body focus, materialism, and need for arousal.

\subsection{Financial Management Behavior}

According to Soekidjo (in Sunaryo, 2004), human behavior is a variety of activities carried out by an individual with himself or carried out together with other individuals. Green (in Notoatmodjo, 2012) states that the behavior of a human being is formed from three factors including:

1. Predisposing factor

Predisposing factors are human abilities that are closely related to the knowledge, attitudes, beliefs, values, perceptions, and motivations of an individual to act.

\section{Enabling factor}

Enabling factors are supporting factors for the conduct of certain behavior by an individual such as the skills and resources possessed by the individual.

\section{Reinforcing factor}

The reinforcing factor is the driving or supporting factor which is an external factor that also influences the behavior that will or is taken by an individual, for example in the environmental conditions where the individual is located.

According to Kholilah and Iramani (2013), financial management behavior arises due to the large desire of an individual for the fulfillment of the needs that the individual wants but is limited by the level of income owned by the individual, so that it can be interpreted that the ability of an individual to manage daily financial resources in order to meet the needs of an individual life is the meaning of financial management behavior. According to Dew and Xiao (in Mien and Thao, 2015) the indicators used to measure the financial management behavior of an individual are cash management, credit management, and saving and investment. 


\subsection{Hypothesis Development}

A hypothesis is a temporary conclusion that comes from observations and theories of previous research made by someone. Based on the background and problems as well as the objectives to be achieved in this study, the following are the hypotheses of this research:

1. The influence of financial knowledge on personal financial management behavior.

Financial knowledge according to Ahillah (2019) is knowledge of basic financial aspects, knowledge of credit, knowledge of interest rates, knowledge of investment. The results of research by Mien and Thao (2015) state that financial attitude and financial knowledge have a positive and significant influence on financial management behavior. Research conducted by Humaira (2018) also proves that financial knowledge, financial attitudes, and personality have a positive and significant influence on financial management behavior. Based on these two studies, it can be concluded that financial knowledge has an effect on personal financial management behavior, so the hypothesis is formulated as follows:

H1: Financial knowledge possessed by educators will affect the personal financial management behavior of educators.

2. The influence of financial attitude on personal financial management behavior.

Financial attitude is a state, thoughts, opinions, and judgments about finance that are applied to attitudes (Pankow 2003). The results of research by (Setiawan et al., 2016) state that there is a positive and significant influence between social demographics, financial knowledge, and attitudes with individual financial investment behavior. Research by Dwiastanti (2017) also provides evidence that financial attitude has a significant influence on locus of control and financial management behavior. Based on these two studies, it can be concluded that financial attitude affects personal financial management behavior, so the hypothesis is formulated as follows:

$\mathrm{H}$ 2: Financial attitude possessed by an educator will affect the personal financial management behavior of educators.

3. The influence of personality traits on personal financial management behavior.

Carl (in Setiawan et al., 2016) states that personality is all real thoughts, feelings, and behaviors both consciously and unconsciously. Big five personality traits is a personality theory that explains the relationship between cognitive, affective, and psychomotor to the behavior taken by an individual (Caprara and Cervone, 2000). Research by Sina (2014) states that 
understanding personality in managing finances is a necessity. Research by Bertoni et al. (2019) also provides evidence that several dimensions of personality traits including consciousness, risk aversion, and neuroticism have a significant influence on the attitude of individual availability in making investments, so based on these studies the research hypothesis is formulated as follows:

H3: Personality Traits owned by educators will affect the personal financial management behavior of educators.

\section{METHODOLOGY}

This research is quantitative research with the type of explanatory research. This study has a population of all educators at one Islamic boarding school in Ponorogo City with a total of 31 people. The sampling technique in this study used a saturated sampling technique or a census. This research was carried out from February to March 2021. The data analysis technique in this study used the PLS structural equation model with the help of the SmartPLS 3.0 program. The PLS structural equation model has 3 stages of analysis, namely outer model analysis, inner model analysis, and hypothesis testing.

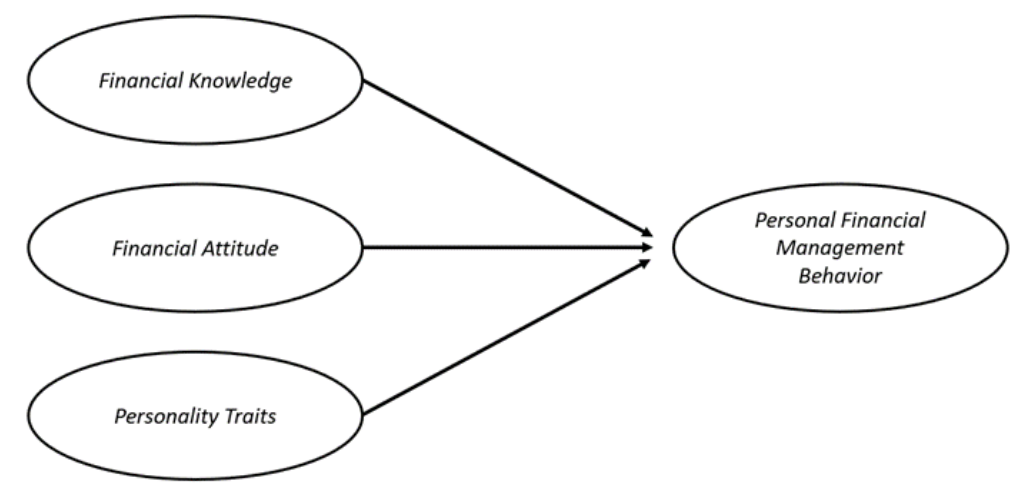

Figure 1. Research model 


\section{RESULT AND DISCUSSION}

Based on the data obtained, it can be seen that the majority of respondents are women, as many as 28 respondents or $90.3 \%$. Meanwhile, male respondents only amounted to 3 people or $9.7 \%$.

Judging from the age range of the respondents in this study, it was dominated by respondents with an age range of 21 to d. 30 years with a total of 29 people or $93.5 \%$ of the total respondents. While other respondents have an age range of 31 s.d. 40 years with a total of 2 people or $6.5 \%$ of the total number of respondents.

Judging from the last education possessed by the respondents, the respondents of this study were dominated by respondents with the last education of bachelor's degree with a total of 20 people or $64.5 \%$ of the total number of respondents. Meanwhile, other respondents have the last education of master's degree with a total of 11 people or $35.5 \%$ of the total number of respondents.

Table 1. The profile of respondents

\begin{tabular}{|c|c|c|c|}
\hline Respondent Characteristic & & Frequencies & Percentage \\
\hline \multicolumn{4}{|l|}{ Gender } \\
\hline Male & & 3 & $9.7 \%$ \\
\hline Female & & 28 & $90.3 \%$ \\
\hline & Total & 31 & $100 \%$ \\
\hline \multicolumn{4}{|l|}{ Age } \\
\hline 21-30 years old & & 29 & $93.5 \%$ \\
\hline $31-40$ years old & & 2 & $6.5 \%$ \\
\hline & Total & 31 & $100 \%$ \\
\hline \multicolumn{4}{|l|}{ Education } \\
\hline Bachelor's degree & & 20 & $64 \%$ \\
\hline Master's degree & & 11 & 35.5 \\
\hline & Total & 31 & $100 \%$ \\
\hline
\end{tabular}

Source : Research data (2021)

\subsection{Outer Model Analysis}

According to Ghozali and Kusumadewi (2016), the outer model analysis stages are carried out to test the validity and reliability of a research construct consisting of: 


\section{Convergent validity}

It is a validity test that is assessed based on the loading factor value for each construct indicator. If the loading factor value $>0.5$, it is said to be valid and can be used for SEM-PLS analysis. Based on the results of the convergent validity test, all indicators used to measure the variables in this study were declared valid because they had a loading factor value of more than 0.5 .

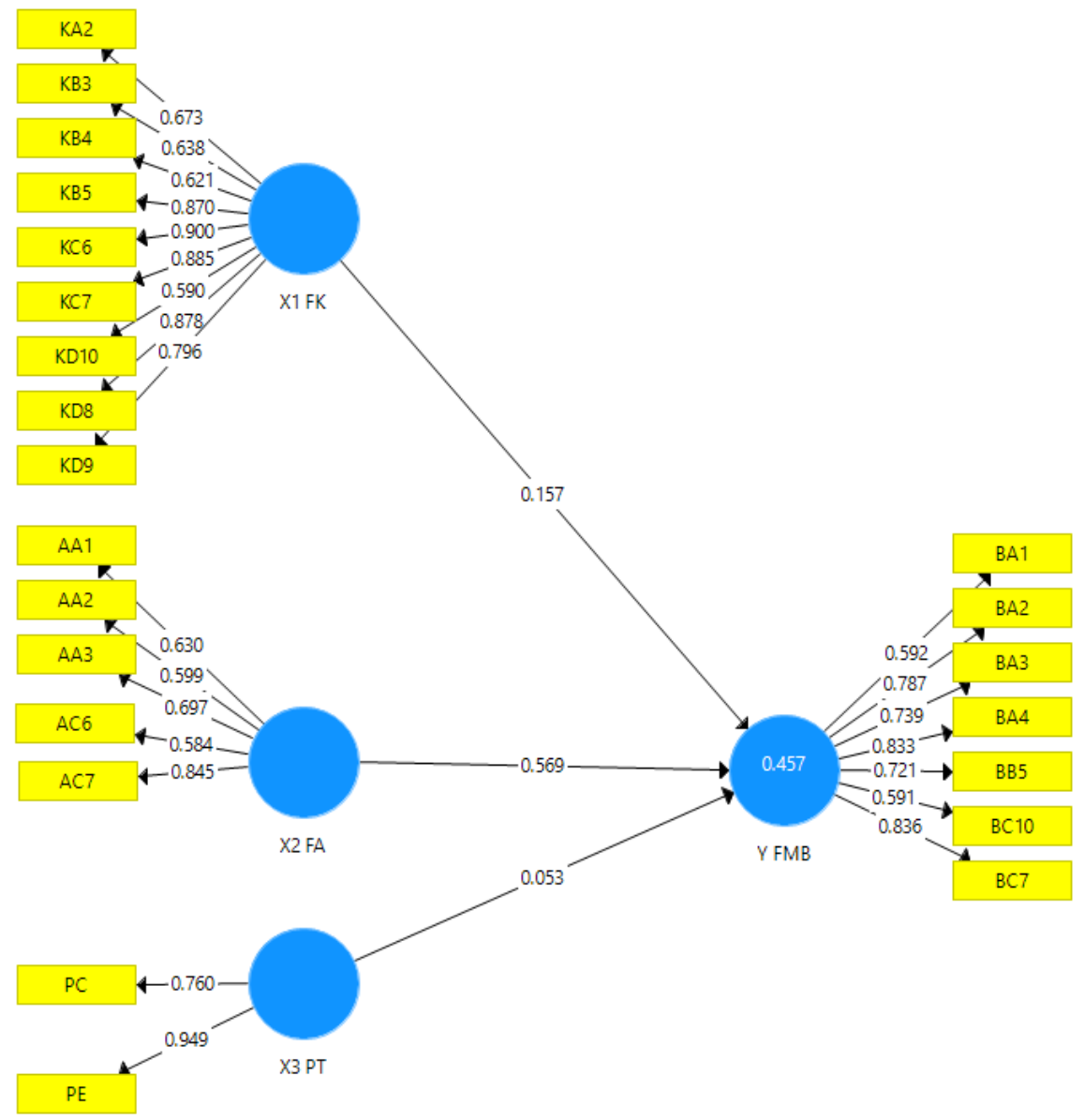

Figure 2. Loading Factor

2. Discriminant validity

It is a validity test that is assessed based on the cross-loading value. The indicator is said to be valid if the correlation of the construct with the measurement item is greater than the size of the other constructs. Based on the results of the discriminant validity test, all indicators used to measure the variables in this study were declared valid because the correlation of variables with measurement items was greater than the size of other variables. 
Table 2. Cross-loading

\begin{tabular}{ccccc}
\hline & FK & FA & P & FMB \\
\hline AA1 & 0.230 & $\mathbf{0 . 6 3 0}$ & 0.305 & 0.286 \\
AA2 & 0.261 & $\mathbf{0 . 5 9 9}$ & 0.328 & 0.186 \\
AA3 & 0.144 & $\mathbf{0 . 6 9 7}$ & 0.318 & 0.493 \\
AC6 & 0.338 & $\mathbf{0 . 5 8 4}$ & 0.333 & 0.308 \\
AC7 & 0.430 & $\mathbf{0 . 8 4 5}$ & 0.363 & 0.681 \\
BA1 & 0.304 & 0.168 & 0.338 & $\mathbf{0 . 5 9 2}$ \\
BA2 & 0.318 & 0.417 & 0.383 & $\mathbf{0 . 7 8 7}$ \\
BA3 & 0.234 & 0.605 & 0.282 & $\mathbf{0 . 7 3 9}$ \\
BA4 & 0.366 & 0.633 & 0.150 & $\mathbf{0 . 8 3 3}$ \\
BB5 & 0.189 & 0.560 & 0.210 & $\mathbf{0 . 7 2 1}$ \\
BC7 & 0.433 & 0.225 & 0.118 & $\mathbf{0 . 5 9 1}$ \\
BC10 & 0.326 & 0.521 & 0.321 & $\mathbf{0 . 8 3 6}$ \\
KA2 & $\mathbf{0 . 6 7 3}$ & 0.149 & -0.104 & 0.208 \\
KB3 & $\mathbf{0 . 6 3 8}$ & 0.333 & 0.224 & 0.205 \\
KB5 & $\mathbf{0 . 6 2 1}$ & 0.482 & 0.155 & 0.379 \\
KC6 & $\mathbf{0 . 8 7 0}$ & 0.311 & 0.034 & 0.402 \\
KC7 & $\mathbf{0 . 9 0 0}$ & 0.412 & 0.029 & 0.420 \\
KD8 & $\mathbf{0 . 8 7 8}$ & 0.351 & 0.098 & 0.337 \\
KD9 & $\mathbf{0 . 7 9 6}$ & 0.252 & 0.114 & 0.220 \\
KD10 & $\mathbf{0 . 5 9 0}$ & 0.212 & -0.023 & 0.245 \\
PC & -0.046 & 0.273 & $\mathbf{0 . 7 6 0}$ & 0.174 \\
PE & 0.163 & 0.488 & $\mathbf{0 . 9 4 9}$ & 0.361 \\
\hline SourCe & & & \\
\hline
\end{tabular}

Source : Research data (2021)

3. Composite reliability

It is a reliability test in PLS. Data that has composite reliability and Cronbach's alpha $>0.7$ has high reliability and can be used for SEM-PLS analysis. 
Table 2. Composite Reliability

\begin{tabular}{lll}
\hline & & $\begin{array}{l}\text { Composite } \\
\text { Reliability }\end{array}$ \\
\hline 1. & Financial Knowledge & 0.928 \\
2. & Financial Attitude & 0.806 \\
3. & Personality & 0.848 \\
4. & Financial Management & 0.890 \\
& Behavior & \\
\hline Source & research data $(2021)$ &
\end{tabular}

Source : research data (2021)

Based on the results of the composite reliability test, it can be seen that the entire composite reliability value is $>0.7$. This shows that all instruments on each of these variables are reliable.

\subsection{Inner Model Analysis}

The inner model analysis aims to predict the relationship between the hypothesized latent variables. The inner model is evaluated by looking at the percentage of variance explained by looking at the R-Square value for endogenous latent constructs.

Table 3. Inner Model

\begin{tabular}{ll}
\hline Variable & R-Square \\
\hline Financial management behavior & 0.457 \\
\hline
\end{tabular}

Source : research data (2021)

The results of the analysis of the inner model in this study get an R-Square value of 0.457 or $45.7 \%$. This shows that Financial Management Behavior is influenced by $45.7 \%$ by financial knowledge, financial attitude, and personality traits while the remaining $54.3 \%$ is influenced by other variables outside the model.

\subsection{Hypothesis testing}

Table 4. Hypothesis testing

\begin{tabular}{lccc}
\hline Hypothesis & $\begin{array}{c}\text { Path } \\
\text { coefficient }\end{array}$ & t-Statistic & p-Value \\
\hline H1 & 0.157 & 0.710 & 0.478 \\
H2 & 0.569 & 2.546 & 0.011 \\
H3 & 0.053 & 0.315 & 0.753 \\
\hline
\end{tabular}

Source : research data (2021) 
Hypothesis testing in this study was carried out by paying attention to the t-statistic value and $p$-value. If the t-statistic value is more than the t-table, namely 1.96 , and the $p$-value $<0.05$, the hypothesis can be accepted. The following is a description of the hypothesis test based on the hypothesis test table, namely:

1. The relationship between financial knowledge and personal financial management behavior has a t-statistic value of 0.710 with a $p$-value of 0.478 . In addition, the path coefficients show a positive number of 0.157 . These results indicate that financial knowledge has no significant positive effect on personal financial management behavior, so hypothesis 1 is rejected.

2. The relationship between financial attitude and personal financial management behavior has a t-statistic value of 2,546 with a p-value of 0.011 . In addition, the path coefficients show a positive number of 0.569 . These results indicate that financial attitude has a significant positive effect on personal financial management behavior, so hypothesis 2 is accepted.

3. The relationship between personality traits and personal financial management behavior has a t-statistic value of 0.315 with a p-value of 0.753 . In addition, the path coefficients show a positive number of 0.053 . These results indicate that personality traits have no significant positive effect on personal financial management behavior, so hypothesis 3 is rejected

\subsection{Findings and Generally Discussion}

The following is a discussion of the results of hypothesis testing that have previously been carried out which are related to the theory and previous studies that are relevant to this research:

1. The influence of Financial Knowledge on Personal Financial Management Behavior

Based on the results of the study, it can be seen that financial knowledge has no significant positive effect on personal financial management behavior. The results of this study are in accordance with research by (Kholilah and Iramani, 2013) which states that there is no direct effect on the relationship between financial management behavior and financial knowledge and income due to a lack of financial knowledge due to the absence of educational background in finance. The educational background of XYZ Islamic boarding school educators who come from various backgrounds is also the cause of not all or only a small part of them having good financial knowledge. In addition, the results of this study are also in accordance with research by Dwiastanti (2017) which also states that 
financial knowledge has no significant effect on locus of control and financial management behavior. The more financial knowledge an individual has, it does not guarantee that the individual has the ability or attitude to manage good abilities. This statement is supported by (Nababan and Sadalia, 2012) which states that the behavior carried out by an individual is not always influenced by the knowledge possessed by the individual but is also influenced by several other factors which are quite difficult to predict.

The results in this study support the theory of planned behavior (Ajzen, 1991). This theory has the assumption that the behavior of an individual, whether initiated by a certain intention or goal, is motivated by several personal factors. In the theory of planned behavior, the knowledge possessed by an individual is only one of the background factors that do not play a major role in the process of forming an individual's behavior. Based on the Theory of planned behavior, individual behavior carried out by an individual is influenced by 3 main factors, the first is behavioral belief, which is the belief that individuals have on the positive or negative behavior of a behavior. The second factor is normative belief, which is the norms that exist in the individual's environment. The third factor is control belief, which is the individual's personal experience.

2. The influence of Financial Attitude on Personal Financial Management Behavior.

Based on the results of the study, it can be seen that financial attitude has a significant positive effect on personal financial management behavior. The results of this study support research by Ahillah (2019) which states that the financial attitude variable can increase personal financial management behavior so that it has a positive and significant influence. This study also supports research by Humaira (2018) which states that the financial attitude variable has a positive and significant influence on financial management behavior.

The results of this study are in line with the theory of planned behavior (Ajzen, 1991). The theory states that the behavior of an individual, whether initiated by a certain intention or goal, is motivated by several personal factors such as attitudes. Attitudes in the theory of planned behavior are seen as perceived behavioral control that manages an individual's assessment of an object and shapes behavior based on that assessment. If an individual gives a positive value for his attitude, then the individual's behavior will also be good and vice versa. If the theory of planned behavior is related to personal financial management behavior, then the positive assessment that an individual has about his attitude about money will result in good behavior as well. 
The results of this study also strengthen the theory of the psychology of money usage proposed by Furnham in 1984, this theory has the assumption that individuals who have a good financial attitude will have a good mindset about money. Good mindset on money such as perception of the future (obsession), not using money to control other individuals or gain power (power), self-capability to control one's financial condition (effort), adjustment to the use of money to meet the needs of life (inadequacy), and a sense of not wanting to spend the money they have (retention).

3. The Influence of Personality Traits on Personal Financial Management Behavior

Based on the results of the study, it can be seen that personality traits have no significant positive effect on personal financial management behavior. The results of this study are in line with research by Mubarok (2017) which states that an individual's personality does not affect individual financial management behavior due to the lifestyle in the community where the individual lives. The simple environment of the $X Y Z$ Islamic boarding school makes the lifestyles of individuals in that environment have a simple lifestyle too so that the personality of the educators does not affect their financial management behavior.

The results of this study are also in line with research by Nobriyani and Haryono (2019) which also states that the good or bad personality of an individual does not affect the financial management behavior of an individual due to several factors such as the availability of funding sources owned by the individual. Sufficient funding sources for an individual result in the individual's personality does not affect his financial management behavior because the individual feels his needs are fulfilled.

The results of this study are inversely proportional to the theory of big five personality traits by Caprara and Cervone, (2000) which states that an individual's behavior is formed from five personality components which then appear in the form of values, beliefs, character, and attitudes possessed by the individual. Based on the theory of big five personality traits, the better the personality of an individual, the better the behavior of the individual so that the behavior of personal financial management carried out by an individual should also be better.

Although it is inversely proportional to the theory of the big five personality traits. However, the results in this study are in line with the theory of planned behavior which states that an individual's personality is a background factor of an individual's behavior, so it does not play a major role in shaping individual behavior. 


\section{CONCLUSION}

Based on the research results obtained, the following conclusions can be drawn:

1. Financial knowledge possessed by educators does not influence the personal financial management behavior of educators. These results are in line with the theory of planned behavior which views an individual's knowledge as a background factor on an individual's behavior.

2. The financial attitude of an educator influences the personal financial management behavior of educators. These results are in line with the theory of planned behavior which views attitude as perceived behavioral control over the behavior that will be carried out by the individual.

3. Personality owned by educators do not influence the personal financial management behavior of educators. This is in line with the theory of planned behavior which views personality as a background factor for the behavior of an individual.

\subsection{Suggestions}

For further researchers who are considering researching with a similar theme. It is hoped that it will be able to expand the scope of the object of research and add other variables that may affect the management of an individual's finances.

\section{REFERENCE}

Ahillah, L. M., 2019. 'Pengaruh financial attitude dan financial knowledge terhadap personal financial management behavior pada pegawai direktorat jenderal perbendaharaan', Jurnal IImiah Mahasiswa FEB, Vol. 7, No 2.

Ajzen, I., 1991. 'The theory of planned behavior', Organizational behavior and human decision processes, pp. 179-211

Ajzen, Icek. 2005. Attitudes, Personality and Behavior (2nd ed.). Open University Press, New York.

Aprilia, Zenika. 2015. 'Pengaruh Locus of Control, Financial Knowledge dan Personal Income terhadap Financial Management Behavior pada karyawan KPP Pratama Blitar', Skipsi, Universitas Negeri Malang, Malang

Asaff, R., S. \& Rahmayani, R., 2019. 'Pengaruh financial attitude dan financial knowledge terhadap financial management behavior', JEMMA | Jurnal of Economic Management and Accounting, pp. 9-22.

Azwar, Saifuddin. 2013. Sikap manusia: teori dan pengukurannya. Yogyakarta: Pustaka Pelajar. 
Bertoni, M. et al., 2019. 'Personality traits and financial behavior', Health and socioeconomic status over the life course, pp. 49-56.

Caprara, G. V., \& Cervone, D. (2000). Personality: determinants, dynamics, and potentials. Cambridge University Press.

Dwiastanti, A., 2017. 'Analysis of financial knowledge and financial attitude on locus of control and financial management behavior', Management and Business Review, pp. 1-8.

Ghozali, I. \& Kusumadewi, K. A., 2016. Model persamaan struktural. Semarang: Yoga Pratama.

Humaira, I., 2018. 'Pengaruh pengetahuan keuangan, sikap keuangan, dan kepribadian terhadap perilaku manajemen keuangan pada pelaku umkm sentra kerjainan batik kabupaten bantul', Nominal, Barometer Riset Akuntansi dan Manajemen, Vol. 7, No. 1, pp. 96-110.

Kapoor, J. R., Dlabay, L. R., Hughes, R. J. \& Hoyt, W. B., 2007. Business and Personal Finance. California: The McGraw-Hill Companies.

Kholilah, Naila Al \& Iramani, Rr, 2013. 'Studi financial management behavior pada masyarakat surabaya', Journal of Business and Banking, Vol. 3, No. 1, pp. 69-80.

Maghfirah, S. (2019). Pemanfaatan barang bekas dalam meningkatkan kemampuan motorik halus anak. Ațāluna: Journal of Islamic Early Childhood Education, Vol. 2, No. 1, pp 48-52.

Marsh, B. A., 2006. 'Examining the personal finance attitudes, behaviors, and knowledge levels of first-year and senior students at baptist universities in the state of texas. Dissertation Strata-3, State University of Texas, Texas.

Mien, N. T. N. \& Thao, T. P., 2015. 'Factors affecting personal financial management behaviors: evidence from vietnam', Proceedings of the Second AsiaPacific Conference on Global Business, Economics, Finance and Social Sciences (AP15Vietnam Conference), p. 10.

Mubarok, M. H., 2017. 'Pengaruh faktor demografi, pengetahuan keuanganan, personality traits terhadap perilaku pengelolaan keuangan keluarga', Jurnal Ekonomi, Bisnis, Dan Akuntansi (JEBAV).

Nababan, D. \& Sadalia, I., 2012. 'Analisis personal financial literacy dan financial behavior mahasiswa strata i fakultas ekonomi universitas sumatera utara', Media Informasi Manajemen, Vol. 1 No.1.

Nobriyani, A. P. \& Haryono, N. A., 2019. 'Faktor-faktor yang memengaruhi financial management behavior pada keluarga tki di kabupaten ponorogo', Jurnal IImu Manajemen, Vol. 7, No. 3. 
Notoatmodjo, Soekidjo. (2005). Promosi kesehatan teori dan aplikasi. Jakarta: PT. Asdi Mahasatya.

Notoatmodjo, Soekidjo. (2012). Promosi kesehatan dan perilaku kesehatan. Jakarta: Rineka Cipta.

Pankow, Debra. 2003. Financial, values, attitudes and, goals. North Dakota State University Fargo. North Dakota 58105

Pradiningtyas, T. E. \& Lukiastuti, F., 2019. 'Pengaruh pengetahuan keuangan dan sikap keuangan terhadap locus of control dan perilaku pengelolaan keuangan mahasiswa ekonomi', Jurnal Minds: Manajemen Ide dan Inspirasi, pp. 96-112.

Schueffel, P., 2016. 'Taming the beast: a scientific definition of fintech', Journal of Innovation Management, Vol. 4 No. 4, pp. 32-54.

Setiawan, E., Wahyudi, S. \& Mawardi, W., 2016. 'Pengaruh sosial demografi, pengetahuan keuangan, dan sikap keuangan terhadap perilaku investasi keuangan individu (studi kasus pada karyawan swasta di kabupaten kudus)', Doctoral dissertation, Diponegoro University, Semarang.

Shih, T. Y., \& Ke, S. C. 2014. 'Determinates of financial behavior: insights into consumer money attitudes and financial literacy', Service Business, Vol. 8, No. 2, pp. 217-238.

Sina, P. G., 2014. 'Tipe kepribadian dalam personal finance', Jurnal JIBEKA Vol. 8, No. 1, pp. 54-59.

Subiaktono. 2013. 'Pengaruh Personality Traits Terhadap Perencanaan Keuangan Keluarga', Jurnal Dinamika Manajemen, Vol 4, No 2, Universitas Semarang

Sunaryo, S., \& Kes, M. (2004). Psikologi untuk keperawatan. Jakarta: Rajawali Pers. 